\title{
豚の大腸菌症における $2134 \mathrm{P}$ 線毛保有大腸菌の分布
}

\author{
菊池浩久 ${ }^{1 ｝ \quad \text { 末吉益雄 }^{2)} \quad \text { 中澤宗生 }{ }^{3)}$ \\ 1）広島県東広島家畜保健衛生所（干739 東広島市西条御条町 1-15） \\ 2）農林水産省家畜衛生試験場九州支場（テ891-01 鹿児島市中山町 2702） \\ 3）農林水産省家畜衛生試験場（宁305 つくば市観音台 3-1-1）
}

（1997 年 3 月 21 日受付・ 1997 年 7 月 14 日受理）

要約

豚の新生期, あるいは離乳後下㾥および浮腫病例から分離され, 付着因子 K88, K99, 987P, F41 を産生しない大腸 菌 263 株について, dot-blot ELISA を用いて毒素原性大腸菌付着因子 $2134 \mathrm{P}$ 線毛の保有状況を調べた。離乳後下痢例 由来 85 株中 7 株（8.2\%）に $2134 \mathrm{P}$ 線毛が認められ，3株（O141：H4）はSTa と VTを，2 株（OUT：H-）は STa のみを, 1 株 $(\mathrm{O} 8: \mathrm{H}-)$ は STa と LT を, 1 株 $(\mathrm{O} 141: \mathrm{H} 4)$ はVT のみを産生した.

—キーワード：大腸菌，離乳後下㢉， $2134 \mathrm{P}$.

日獣会誌 50，596～598（1997）

豚の大腸菌症は原因となる大腸菌の血清型や毒素, 付 着因子等の病原因子および発病機序の違いから大腸菌性 下痢 (新生期下痢, 離乳後下痢), 大腸菌性腸管毒血症 (浮腫病), 大腸菌性敗血症などに大別される 6$]$.この うち, 下痢や腸管毒血症の発生には, 原因大腸菌の腸管 内での付着・定着が感染の初期段階にきわめて重要で, ある種の線毛はこの過程に関与し線毛性付着因子と呼ば れる [3].

毒素原性大腸菌（ETEC）は新生期下刑および離乳後 下㢉の主要な原因菌であり，付着因子として K88，K99， 987P, F41 などが知られている $[3,6]$. また, ベロ毒素 産生性大腸菌 (VTEC) O 群 139 は浮腫病の原因菌であ り [5], 付着因子として F107 線毛 [1] や K12 抗原 [9] が 報告されている.

最近, 離乳後下痢由来大腸菌に既知の付着因子 K88, K99，987P および F41 線毛を欠くが新しい線毛性付着 因子 $2134 \mathrm{P}$ 線毛を保有する株の存在が報告され [7], 離 乳後に発生する大腸菌性下麻や腸管毒血症における本線 毛保有大腸菌の関与に興味があたれている.

そこで，わが国の病豚から分離された大腸菌について, $2134 \mathrm{P}$ 線毛の保有状況を調查し, 大腸菌症との関連を検 討した.

\section{材料おょび方法}

供試大腸菌：豚の新生期下痢（生後 10 日以内の下 痢：ND）由来 58 株, 離乳後下痢（離乳後 14 日以内の 下痢：PWD）由来 85 株および腸管毒血症（浮腫病： ED）由来 120 株の総計 263 株を供試した. このうち, 128 株はETEC，130株はVTEC，5株はETEC と VTEC
の両方に属するあのである.

検査方法：供試菌株の K88, K99，987P および F41 線毛の保有は既報 $[10]$ に従い調べた. 2134P 線毛の検出 は Dean-Nystrom ら [2]の dot-blot ELISA で実施した. 抗原としてはトリプチケースソイブロス ${ }^{\mathrm{a})} 37^{\circ} \mathrm{C}, 20$ 時間静置培養した菌液を用い，その $4 \mu l$ をニトロセル ロース膜bに吸着後, 一次抗体として $2134 \mathrm{P}$ 線毛のモノ クローナル抗体 $\mathrm{mAb} 6 \mathrm{C} 7 / \mathrm{C} 1$ (1:4,000, 米国農務省 Dean-Nystrom 博士より分与) を, 二次抗体としてアル カリホスファターゼ標識抗マウス IgG 山羊血清c) (1 : 20,000）を用い, 常法により発色させた. 血清型別, 産 生毒素の検出および溶血性は既報 $[8,10]$ に従って調べた.

$$
\text { 成績 }
$$

線毛の保有状況：供試した ND 由来 58 株, PWD 由 来 85 株および $\mathrm{ED}$ 由来 120 株から既知の線毛性付着因 子 K88, K99, 987P および F41 は検出されなかった. dot blot ELISA により 2134P 線毛保有大腸菌は明瞭な 発色を呈した。 その陽性像を図 1 に示す。新たな付着因 子 $2134 \mathrm{P}$ 線毛は, PWD 由来 85 株中 7 株 $(8.2 \%)$ に認 められたが, ND および ED由来株からはまったく検出 されなかった（表 1 ）。これら $2134 \mathrm{P}$ 線毛保有大腸菌が 分離された地域は関東 ( 3 株), 四国 ( 3 株) および九 州（1 株）であり（表 2 ), 離乳豚の下痢便あるいは死 亡例の小腸内容物から分離された。

$2134 \mathrm{P}$ 線毛保有大腸菌の性状 : 本線毛産生大腸菌 7 株

\footnotetext{
a) BBL (Becton Dickinson), U.S.A.

b) ADVANTEC TOYO, 東京.

c) Jackson ImmunoResearch Laboratories, Inc., U.S.A.
} 


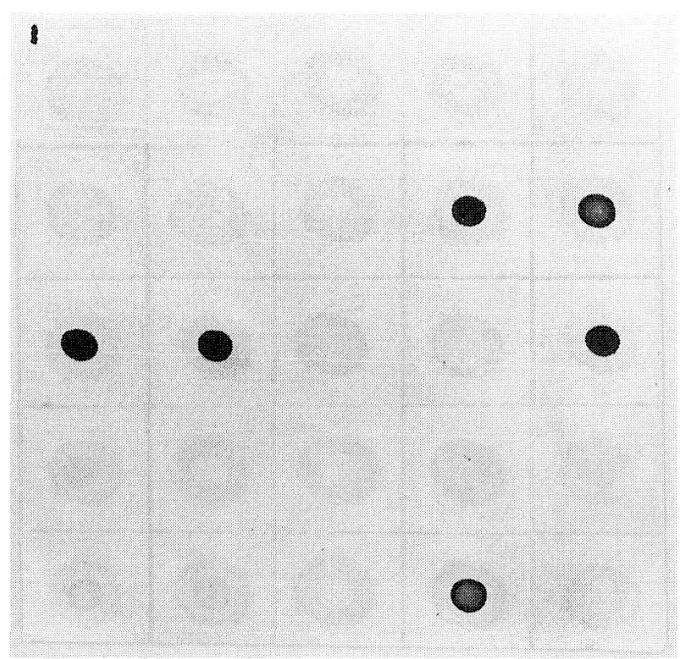

図 1 dot-blot ELISA の 2134P 線毛陽性像.

表 $12134 \mathrm{P}$ 線毛保有大腸菌の検出状況

\begin{tabular}{|c|c|c|c|c|}
\hline \multirow{2}{*}{ 由 } & & \multirow{2}{*}{ 株数 } & \multicolumn{2}{|c|}{ 2134P 線毛 } \\
\hline & & & 陽性株数 & 陰性株数 \\
\hline \multirow{3}{*}{$\begin{array}{l}\text { 新生期下俩 (ND) } \\
\text { 離乳後卜梸 (PWD) }\end{array}$} & ETEC & 58 & 0 & 58 \\
\hline & ETEC & 70 & 3 & 67 \\
\hline & VTEC & 10 & 1 & 9 \\
\hline \multicolumn{2}{|c|}{ ETEC + VTEC } & 5 & 3 & 2 \\
\hline 腸管毒血症 (ED) & VTEC & 120 & 0 & 120 \\
\hline \multicolumn{2}{|l|}{ 計 } & 263 & 7 & 256 \\
\hline
\end{tabular}

PWD 由来 85 株中 7 株（8.2\%）が $2134 \mathrm{P}$ 陽性.

表 2 2134P 線毛保有大腸菌の性状

\begin{tabular}{|c|c|c|c|c|}
\hline 菌株No. & 血清型 & 溶血性 & 産生毒毒 & 分離地域 \\
\hline 1 & OUT : $\mathrm{H}^{-}$ & - & $\mathrm{STa}$ & 関東 \\
\hline 2 & OUT:H- & - & STa & 関東 \\
\hline 3 & $\mathrm{O} 8: \mathrm{H}-$ & + & STa, LT & 関東 \\
\hline 4 & O141 : H4 & + & STa, VT & 四国 \\
\hline 5 & O141 : H4 & + & STa, VT & 四国 \\
\hline 6 & O141 : H4 & + & STa, VT & 四国 \\
\hline 7 & O141 : H4 & + & VT & 九州 \\
\hline
\end{tabular}

OUT : O 群型別不能.

の血清型は O141：H4 が 4 株, O8：H-が 1 株および O 群別不能 (OUT) : H一が 2 株であった。 また，それらの 産生毒素はSTa とVT の両毒素産生株 3 株 (O141 : H4), STa単独産生株 2 株 (OUT : H-), STa と LT の両毒素産生株 1 株 (O8：H-) および VT 単独産生株 1 株（O141：H4）であり，7株中 5 株は溶血性大腸菌 であった（表 2 ).

$$
\text { 考察 }
$$

豚の大腸菌性下痢は罹患豚の日齢により NDと PWD に区分することができるが，原因菌の主体は共通して ETEC である [3]. ND 由来 ETEC は K88，K99，987P，
F41 線毛などの付着因子を保有する株が多いのに対し， PWD 由来 ETEC では既知の線毛性付着因子を保有す る株が少ない傾向があり，これらの線毛非保有株に未知 の線毛性付着因子の存在が予测されていた[10]. Nagy ら [7]は PWD 由来 ETEC に 2134P 線毛を見いだし，本 線毛が生後 3 週齢以降の子豚の腸管粘膜上皮に付着能を 有することから PWD 起因大腸菌の新しい線毛性付着因 子とみなした。

今回のわれわれの成績もこの報告を支持しており， $2134 \mathrm{P}$ 線毛は PWD 由来で既知の線毛陰性の大腸菌のみ が保有しており，ND および $\mathrm{ED}$ 由来株からは検出され なかった.このように本線毛が NDではなく PWD 由来 株に涊められたことは，Nagy ら[7]が指摘するように， 本線毛に対する腸管内レセプターの発現が日歯と関連す ることを反映しているあのと考えられる。また， Kennan ら [1]はスウェーデンに抬ける本線毛の保有率 を $10.1 \%$ と報告しており，わが国では $8.2 \%$ あるあこと からほぼ同様の分布をしているものと思われる。今回の 供試菌株数は限られたあのではあるが，わが国において 6本線毛保有大腸菌が離乳後下痢に関与している可能性 が示唆された。

これまでの報告 [7]では本線毛保有株は離乳豚の下痢 に関連しており，ETEC 特有の線毛と考えられている. しかし, 今回の成績では 7 株中 3 株はETECであった が，3株はSTa と同時にVTを産生し，また 1 株はVT 単独産生菌であることから，本線毛は ETEC に限らず VTECにも存在することが明らかになった。興味ある ことに, 血清型 O141：H4 に属し STa, VT両毒素産生 株は四国で発生した離乳後下痢から分離されたものであ るが，病豚の約 30\%は下痢発症後急死しており，この 発生例においてはSTa 之同時にVTも本病態に関与し たことがうかがえる，豚の場合，VT は浮腫病の原因毒 素であることが明らかにされているが[5], STa および VT 両毒素産生株と浮腫病あるいは急死との関係につい ては今後子豚への実験的投与試験を行い検討しなければ ならない。

大腸菌の腸管感染に重要な働きをする付着因子につい ては，未だ不明な部分が多く，2131P 線毛のような新た な付着関連抗原の存在を明らかにすることで, 本菌感染 症の診断・予防法を確立するための重要な手掛かりが得 られるものと考える.

\section{引用文 献}

[1] Bertschinger HU, Banchmann M, Mettler C, et al : Vet Microbiol, 25, 267-281 (1990)

[2] Dean-Nystrom EA, Casey TA, Schneider RA, et al : Vet Microbiol, 37, 101-114 (1993)

[3] Fairbrother JM : Diseases of swine, Leman AD, et al, eds, 7 th ed, 489-497, Iowa State University 
Press, Iowa (1992)

[4] Kennan R, Soderlind O, Conway P : Vet Microbiol, 43, 123-129 (1995)

[5] MacLeod DL, Gyles CL, Wilcock BP : Vet Pathol, 28, 66-73 (1991)

[6] Morris JA, Sojka WJ : The virulence of Escherichia coli, Sussman M, ed, 47-77, Academic Press, London (1985)
[7] Nagy B, Casey TA, Whipp SC, et al : Infect Immun, 60, 1285-1294 (1992)

［8］中澤宗生, 甲斐明美 : 感染症誌，68，1437-1439（1994）

［9］ 中澤宗生, 片岡 康, 大宅辰夫：日細菌誌，50，551555 (1995)

[10] Nakazawa M, Sugimoto C, Isayama $Y$, et al : Vet Microbiol, 13, 291-300 (1987)

\section{Detection of The 2134P Fimbriae in Escherichia coli Isolates from Pigs} with Colibacillosis

Hirohisa KIKUCHI, Masuo SUEYOSHI and Muneo NAKAZAWA

Higashi-Hiroshima Livestock Health \& Hygiene Service Center, Hiroshima Prefecture, 1-15

Gojo-cho Saijo, Higashi-Hiroshima 739, Japan

\section{SUMMARY}

A total of 263 Escherichia coli strains without K88, K99, 987P and F41 fimbriae, which were isolated from pigs with neonatal diarrhea, postweaning diarrhea or edema disease, were examined for a novel adhesin factory of enterotoxigenic $E$. coli, $2134 \mathrm{P}$, using dot-blot immunoassay. The $2134 \mathrm{P}$ fimbriae were found in 7 (8.2\%) of 85 isolates from postweaning diarrhea cases and 3 strains (O141: H4) produced both STa and VT, while 1 (O8: $\mathrm{H}-)$ both STa and LT. The remaining $2\left(\mathrm{OUT}: \mathrm{H}_{-}\right)$and $1(\mathrm{O} 141: \mathrm{H} 4)$ produced STa alone and VT alone, respectively. - Key words : E. coli, postweaning diarrhea, $2134 \mathrm{P}$.

J. Jpn. Vet. Med. Assoc., 50, 596 598 (1997)

\section{日 本 産 業動物 獣医 学会誌 編 集 委員会委員}

\section{【編 集 委 員】}

○小野憲一郎 (東 京大学 農 学 部)

○稲葉 右二（日本大学生物資源科学部）

梅村 孝司 (鳥 取 大 学農 学 部)

小野 和弘（千葉県農業共済組合連合会）

金田 義宏（東 京 農 工大学農 学 部)

\section{【専門審查委員】}

柚木 弘之（元鹿 児島大学農学部）

平詔亨（農林水産省家畜衛生試験場）

明石 博臣（農林水産省家畜衛生試験場）
杉本 千尋 (北海 道大学 獣医 学 部)

松坂 尚典 (岩手大学農学 部)

後藤 公吉 (新潟県衛生公害研究所)

【編集専門委員】

藤原 公策（日本大学生物資源科学部）

（@委員長, ○副委員長)

編集人日本産業動物獣医学会 会長 浜名克己 